\title{
Analisis Indeks Kekeringan Meteorologis di Bagian Utara Kabupaten Lumajang
}

(Analysis of Meteorological Drought Index in the Northern Lumajang Regency)

\author{
RADIAH ULIL ABSARI, GUSFAN HALIK, WIWIK YUNARNI WIDIARTI
}

\begin{abstract}
ABSTRAK
Kekeringan merupakan salah satu masalah yang memiliki dampak terbesar dari seluruh bencana alam di dunia. Kekeringan terjadi akibat berkurangnya ketersediaan air sehingga berdampak pada kebutuhan sumber daya air, sektor pertanian dan lingkungan. Saat musim kemarau di Kabupaten Lumajang bagian utara seringkali mengalami kekurangan air bersih khususnya pada saat musim kemarau. Hal ini yang menjadi dasar penelitian ini untuk memitigasi kekeringan yang terjadi di Kabupaten Lumajang bagian utara. Metode yang digunakan adalah Standardized Precipitation Index (SPI) dimana data masukannya adalah data curah hujan dari tahun 2000 hingga 2019. Hasil dari perhitungan indeks kekeringan diolah untuk mendapatkan peta sebaran kekeringan pada 6 tahun terakhir. Hasil dari studi ini menunjukan bahwa SPI-12 memiliki kesesuaian dengan data dropping air bersih sehingga nilai indeks kekeringan SPI-12 digunakan untuk mendapatkan peta sebarannya. Pada perhitungan SPI-12, kekeringan tertinggi terjadi pada bulan September 2018 dengan nilai -1,89 (sangat kering) dan hasil sebaran kekeringan pada tahun 2018 didominasi oleh status sangat kering dan hanya sebagian kecil mengalami kondisi kering.
\end{abstract}

Kata Kunci: SPI, kekeringan meteorologis, kekeringan.

\begin{abstract}
Drought is one of the problems that have the biggest impact on all-natural disasters in the world. Drought occurs due to reduced water availability, so that it impacts the needs of water resources, the agriculture sector, and the environment. During the dry season, the northern part of Lumajang often experiences a lack of clean water, especially during the dry season. This is the basis of this research to mitigate the drought that occurred in the northern Lumajang Regency. The method used is the Standardized Precipitation Index (SPI), where the input data is rainfall data from 2000 to 2019. Then the drought index is obtained and must be analyzed to get a map of the spread of drought in the last six years. This study shows that SPI-12 is in suitability with clean water-dropping data so that the drought index value of SPI-12 is used to obtain the distribution map. In the calculation of SPI-12, the highest drought occurred in September 2018 with a value of -1,89 (very dry), and the spread of drought in 2018 was dominated by very dry status, and only a small percentage experienced dry condition.
\end{abstract}

Keywords: SPI, meteorological drought, drought.

\section{PENDAHULUAN}

Kekeringan merupakan fenomena lokal atau regional alami yang disebabkan karena kurangnya curah hujan selama periode waktu tertentu (Livada \& Assimakopoulos, 2007).
Kekeringan bukan hanya kejadian fisik yang didefinisikan oleh kondisi cuaca. Kekeringan didefinisikan sebagai cuaca kering dengan jangka waktu yang lama sehingga mengakibatkan kekurangan air dan kerusakan tanaman (Shah, Bharadiya, \& Manekar, 2015). Kekeringan diakibatkan karena kurangnya jumlah curah hujan dibawah normal atau tidak 
terjadi hujan dalam jangka waktu yang panjang sehingga ketersediaan air di dalam tanah tidak dapat terpenuhi untuk kebutuhan (Suwiji, 2019). Kekeringan meteorologis dapat diikuti dengan kekeringan hidrologis yang mempengaruhi aliran sungai, di danau, dan pengisian ulang aquifer. Jika periode kekeringan berkepanjangan maka dapat menyebabkan perubahan sosial-ekonomi (Awchi \& Kalyana, 2017).

Kekeringan dapat diklasifikasikan menjadi empat jenis menurut Badan Nasional Penanggulangan Bencana, yaitu: kekeringan meteorologis, hidrologis, pertanian, dan sosialekonomi. Kekeringan meteorologis didefinisikan sebagai kondisi dimana curah hujan tahunan di bawah normal dalam suatu daerah dengan jangka waktu yang lama (bulan, musim, tahun). Kekeringan hidrologis adalah ketersediaan air tanah dan air permukaan berada dibawah rata-rata. Kekeringan pertanian merupakan kondisi berkurangnya air tanah dalam proses pertumbuhan tanaman selama kurun waktu tertentu. Kekeringan sosial-ekonomi adalah kondisi komoditas ekonomi kurang dari rata-rata kebutuhan hidup karena terjadinya kekeringan meteorologis, hidrologi dan pertanian.

Kabupaten Lumajang di bagian utara menjadi salah satu wilayah rawan terjadinya kekeringan sehingga berdampak terhadap kesulitan mendapatkan air bersih. Menurut Badan Penanggulangan Bencana Daerah (BPBD) Lumajang, pada Agustus 2019 telah terjadi kekeringan pada 6 kecamatan meliputi Ranuyoso, Klakah, Randuagung, Padang, Kedungjajang, dan Gucialit.

Upaya dalam memahami karakteristik iklim pada wilayah utara Kabupaten Lumajang khususnya pada Kecamatan Ranuyoso, Klakah dan Randuagung dengan baik maka perlu dilakukan mitigasi kekeringan pada wilayah tersebut. Indeks kekeringan merupakan salah satu upaya untuk memantau dan menganalisis tingkat kekeringan suatu daerah. Salah satu metode yang umum digunakan dalam menentukan indeks kekeringan adalah Standardized Precipitation Index (SPI). SPI memiliki beberapa keuntungan termasuk fleksibiliatas dan kemudahan dalam pengoprasian, serta dapat disesuaikan skala waktunya (Tatli, 2015). Selain itu, standardized precipitation index direkomendasikan oleh "Lincoln declaration on drought indices" yang mendorong penggunaan SPI dalam bidang meteorologi dan hidrologi di seluruh dunia (Stagge et al., 2015). Dibandingkan dengan indeks dan metode lain berdasarkan cara kerjanya, misalnya Palmer Drought Severity Index (PDSI), SPI lebih mudah dihitung dan nyaman untuk diterapkan (Du et al., 2013). Analisis indeks kekeringan juga dapat menunjukan tingkat kekeringan pada masing-masing wilayah.

Analisis indeks kekeringan meteorologis dengan metode SPI telah banyak dipakai oleh beberapa penelitian, diantaranya: Kekeringan meteorologis di Yunani dengan menggunakan metode SPI (Livada \& Assimakopoulos, 2007), analisis indeks kekeringan pada berbagai skala waktu (Wang et al., 2015) dan analisis indeks kekeringan pada kabupaten pati (Insani, 2018) dan analisis meteorologis dengan menggunakan data satelit TRMM dan SPI (Widodo \& Pawitan, 2013)

Dalam penelitian ini, mengetahui bagaimana nilai indeks kekeringan meteorologis di Kecamatan Ranuyoso, Klakah dan Randuagung tahun 2000 - 2019 dan mengetahui persebaran kondisi kekeringan berdasarkan nilai SPI pada 6 tahun sebelumnya. Hasil dari indeks kekeringan nantinya akan dibuat pemetaan persebaran kekeringan menggunakan software ArcGIS.

\section{METODE PENELITIAN}

Lokasi penelitian ini berada di bagian utara Kabupaten Lumajang dengan letak geografis $112^{\circ} 53^{\prime}$ - $113^{\circ} 23^{\prime} \mathrm{BT}$ dan $7^{\circ} 54^{\prime}-8^{\circ} 23^{\prime} \mathrm{LS}$. Wilayah penelitian ini terdiri dari 3 Kecamatan yaitu Kecamatan Randuagung, Ranuyoso, dan Klakah. Peta lokasi penelitian disajikan pada Gambar 1. 


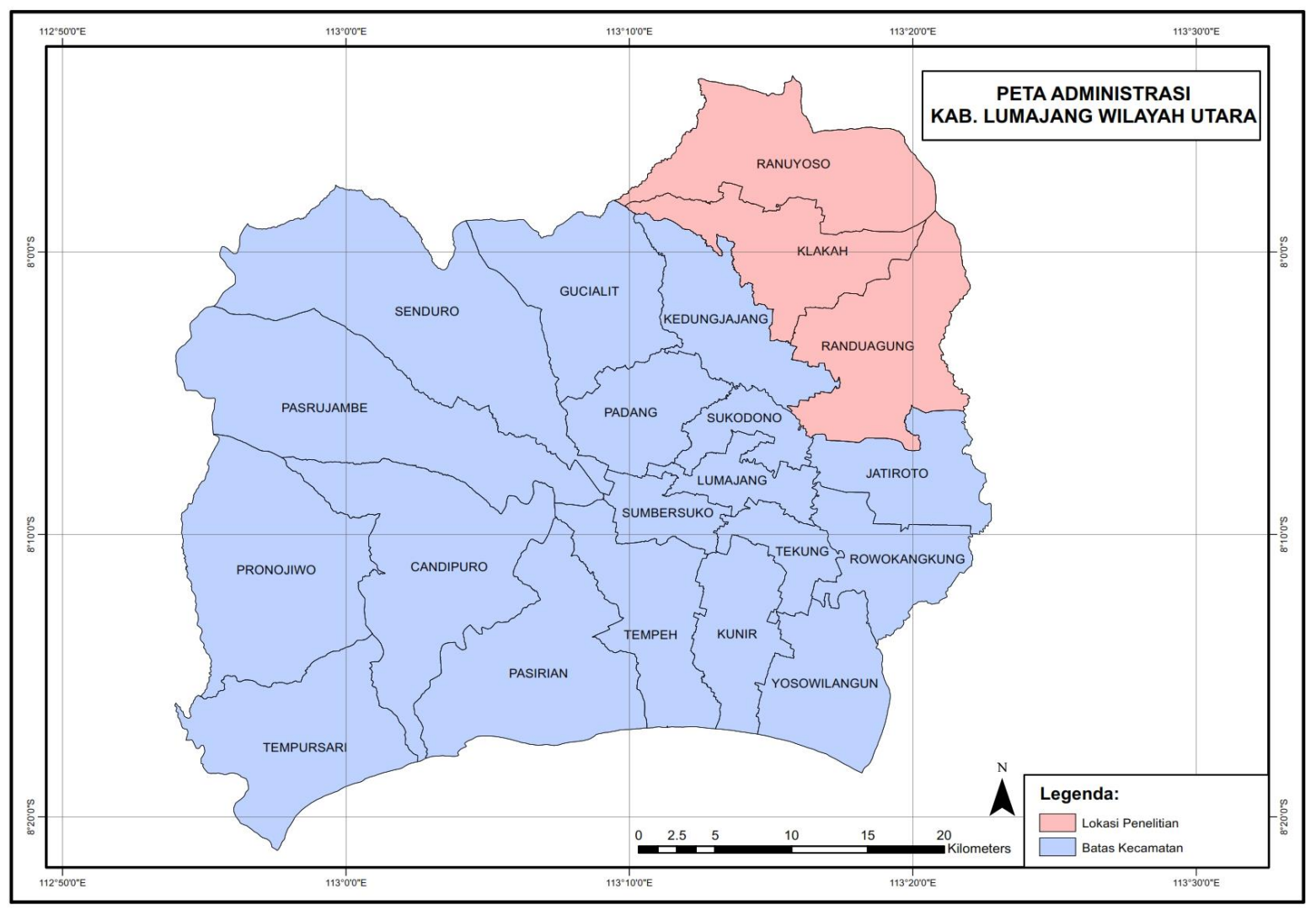

GAMBAR 1. Lokasi Penelitian

Data yang digunakan pada penelitian ini adalah data curah hujan tahun 2000-2019 dari 3 kecamatan yang terdiri dari 7 stasiun hujan. Selanjutnya data dropping air bersih dibutuhkan untuk menjadi bahan validasi hasil analisis.

Metode indeks kekeringan yang dipakai adalah Standardized Precipitation Index (SPI). SPI dapat menggambarkan tingkat kekeringan dalam periode waktu yang panjang maupun pendek. Berikut langkah-langkah analisis SPI:

1. Data curah hujan dari 7 stasiun hujan dilakukan pengujian konsistensi dengan menggunakan metode kurva massa ganda. Uji konsistensi data curah hujan digunakan untuk mengetahui konsisten atau tidaknya data curah hujan yang ada di lokasi penelitian.

2. Uji abnormalitas curah hujan dilakukan dengan menggunakan metode Iwai untuk memeriksa layak atau tidaknya harga maksimum pada curah hujan.
3. Perhitungan nilai indeks kekeringan SPI dapat dirumuskan dengan persamaan 1 3.(Li et al., 2012):

$$
\begin{aligned}
& G(x)=\int_{0}^{x} g(x) d x=\frac{1}{\beta^{\alpha} r \Gamma(\alpha)} \int_{0}^{x} t^{a-1} e^{-x / \beta} d x \\
& S P I=S \frac{t-\left(c_{2} t+c_{1} 0 t+c_{0}\right.}{\left(\left(d_{3} t+d_{2}\right) t+d_{1}\right) t+1,0} \\
& t=\sqrt{\operatorname{In} \frac{1}{(H(x))^{2}}} ; \text { untuk } 0<\mathrm{H}(\mathrm{x}) \leq 0.5 \\
& t=\sqrt{\operatorname{In} \frac{1}{(1-H(x))^{2}}} ; \text { untuk } 0.5<\mathrm{H}(\mathrm{x}) \leq 1
\end{aligned}
$$

4. Dimana nilai $\mathrm{S}$ merupakan koefisien negatif dan positif; $\mathrm{X}$ merupakan curah hujan; $\beta, \gamma$ adalah scale parameter dan shape parameter dari fungsi $\Gamma$. Kemudian hasil perhitungan diklasifikasikan indeks SPI sesuai kategori SPI. Klasifikasi indeks SPI dapat dilihat pada Tabel 1. 
TABEL 1. Klasifikasi nilai indeks SPI

\begin{tabular}{cc}
\hline Nilai SPI & Kategori \\
\hline 2 & Amat Sangat Basah \\
$1,50-1,99$ & Sangat Basah \\
$1,00-1,49$ & Basah \\
$-0,99-0,99$ & Normal \\
$-1,00--1,49$ & Kering \\
$-1,50--1,99$ & Sangat Kering \\
$\leq-2$ & Amat Sangat Kering \\
\hline
\end{tabular}

5. Uji validasi menggunakan data dropping air yang didapatkan dari Badan Nasional Penanggulangan Bencana Kabupaten Lumajang dan disesuaikan dengan hasil analisis SPI.

6. Hasil perhitungan indeks kekeringan kemudian di analisis spasial dengan metode Inverse Distance Weighting (IDW) dan didapatkan peta sebaran kekeringan berdasarkan klasifikasi kekeringannya.

\section{HASIL DAN PEMBAHASAN}

1. Uji Konsistensi Curah Hujan

Pengujian konsistensi dengan metode kurva massa ganda merupakan analisa korelasi dan uji regresi. Berdasarkan hasil perhitungan konsistensi, seluruh nilai koefisien determinasi (R) pada masing-masing stasiun hujan kurang dari 1 yang dapat diartikan tidak terdapat kepanggahan dari data curah hujan tersebut. Hasil koefisien determinasi (R) pada masingmasing stasiun hujan disajikan pada Tabel 2.

TABEL 2. Uji konsistensi stasiun hujan di Kabupaten Lumajang bagian utara

\begin{tabular}{ccc}
\hline Stasiun Hujan & Nilai R & Keterangan \\
\hline Dam Umbul & 0,9973 & Konsisten \\
Gedang Mas & 0,9988 & Konsisten \\
Kali Penggung & 0,9989 & Konsisten \\
Paleran & 0,9991 & Konsisten \\
Ranuklakah & 0,9969 & Konsisten \\
Ranupakis & 0,9982 & Konsisten \\
Ranuyoso & 0,9962 & Konsisten \\
\hline
\end{tabular}




\section{Uji Abnormalitas Curah Hujan}

Uji abnormalitas digunakan untuk mengetahui apakah harga-harga maksimum dari data curah hujan layak digunakan atau tidak. Berdasarkan hasil analisis uji abnormalitas bahwa semua nilai laju abnormalitas pada tiap-tiap stasiun hujan $\varepsilon>\varepsilon_{0}=0,2561$. Sehingga harga-harga maksimum tidak dapat disingkirkan. Hasil perhitungan pada masing-masing stasiun hujan disajikan pada Tabel 3.

\section{Analisis Standardized Precipitation Index} (SPI)

Hasil analisis dari 7 stasiun hujan di Kabupaten Lumajang bagian utara menunjukan nilai yang bervariasi. Dalam perhitungan indeks kekeringan SPI, skala waktu yang digunakan adalah SPI-6, SPI-9 dan SPI-12. Hasil analisis SPI-6 ditampilkan pada Gambar 2. Hasil analisis SPI-9 ditampilkan pada Gambar 3. Hasil analisis SPI-12 ditampilkan pada Gambar 4

TABEL 3. Uji abnormalitas stasiun hujan di Kabupaten Lumajang bagian utara

\begin{tabular}{ccc}
\hline Stasiun Hujan & Laju Abnormalitas (q) & Keterangan \\
\hline Dam Umbul & 3,171 & Tidak dapat disingkirkan \\
Gedang Mas & 3,7313 & Tidak dapat disingkirkan \\
Kali Penggung & 0,9716 & Tidak dapat disingkirkan \\
Paleran & 1,026 & Tidak dapat disingkirkan \\
Ranuklakah & 3,87 & Tidak dapat disingkirkan \\
Ranupakis & 2,405 & Tidak dapat disingkirkan \\
Ranuyoso & 4,121 & Tidak dapat disingkirkan \\
\hline
\end{tabular}

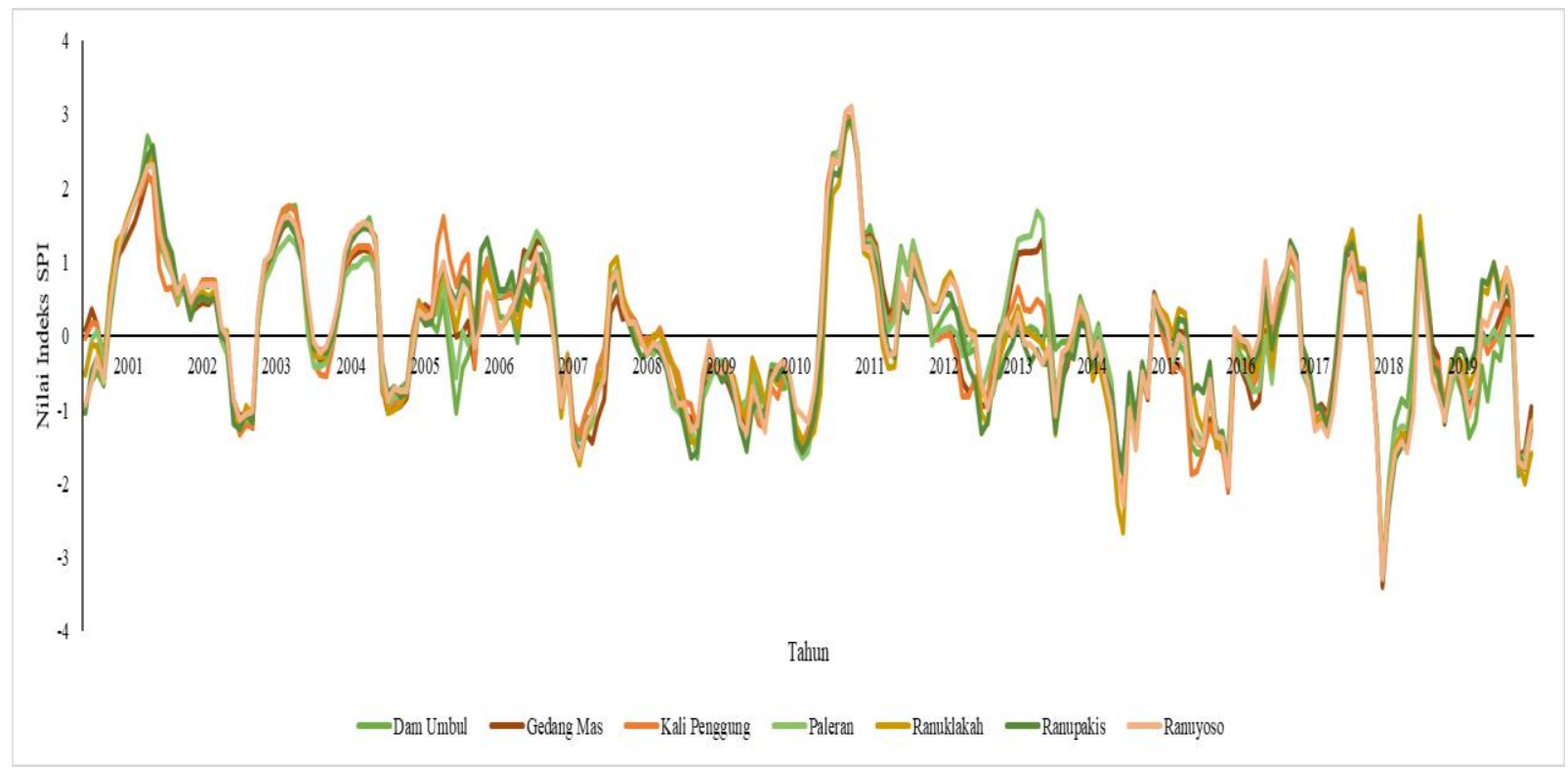

GAMBAR 2. Hasil analisis SPI-6 


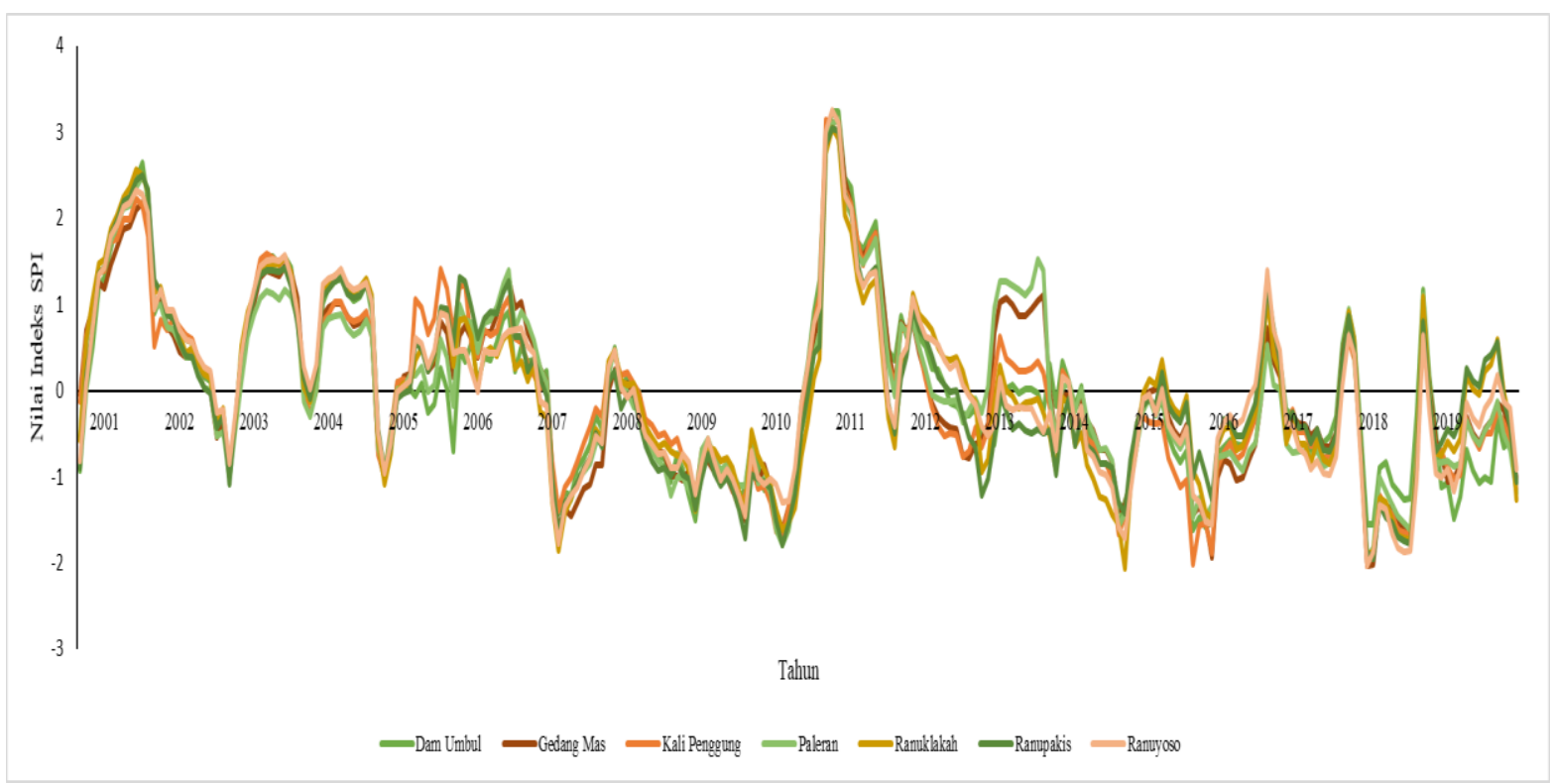

GAMBAR 3. Hasil analisis SPI-9

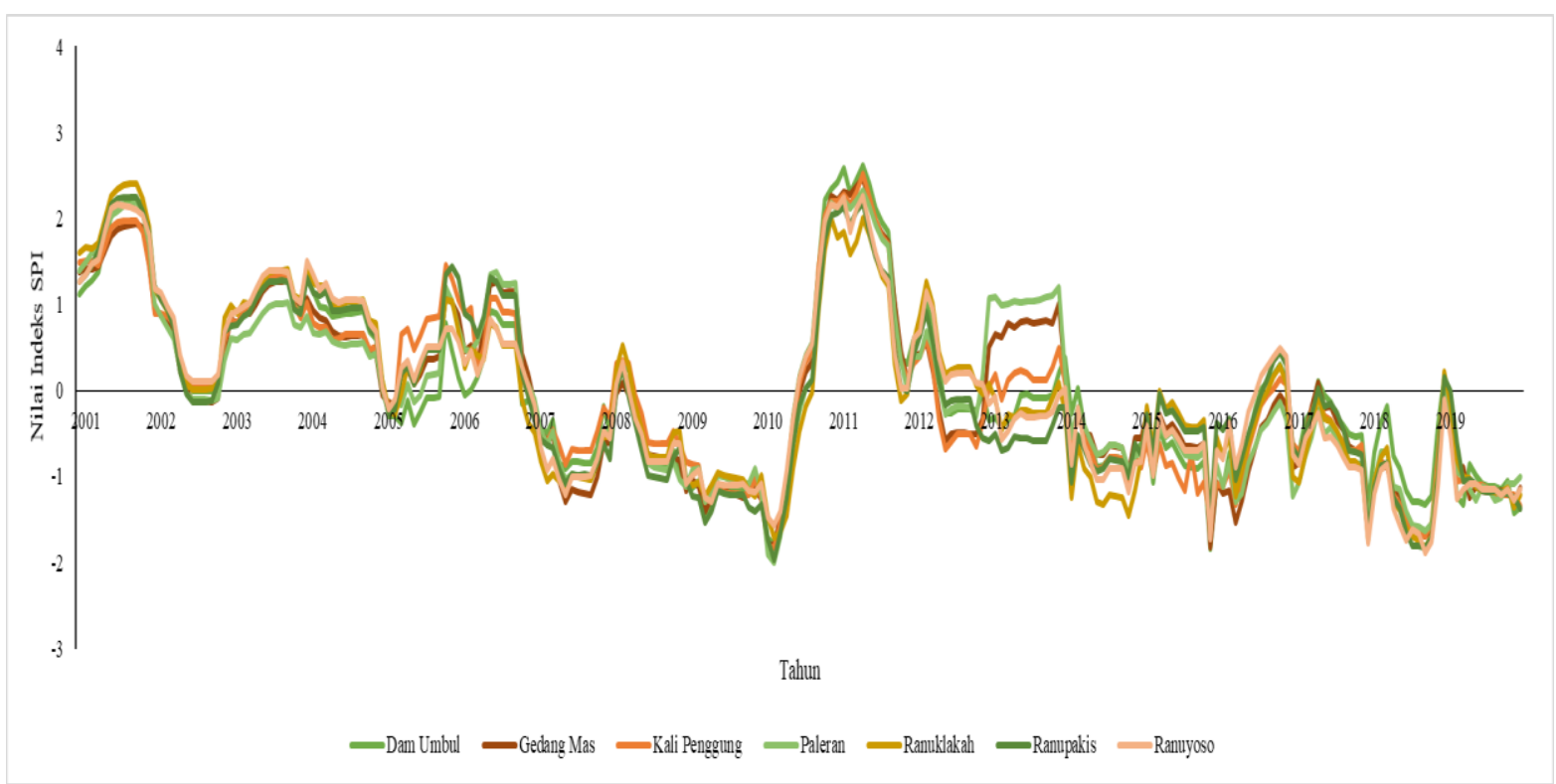

GAMBAR 4. Hasil analisis SPI-12

Hasil analisis SPI dilakukan uji validasi yang dibandingkan dengan data dropping air bersih. Berdasarkan penyesuaian indeks SPI dengan data dropping air, hasil analisis SPI yang memiliki kesesuaian adalah SPI-12. Hal ini ditunjukkan terdapatnya kesesuaian pola indeks SPI-12 dengan data dropping air bersih. 

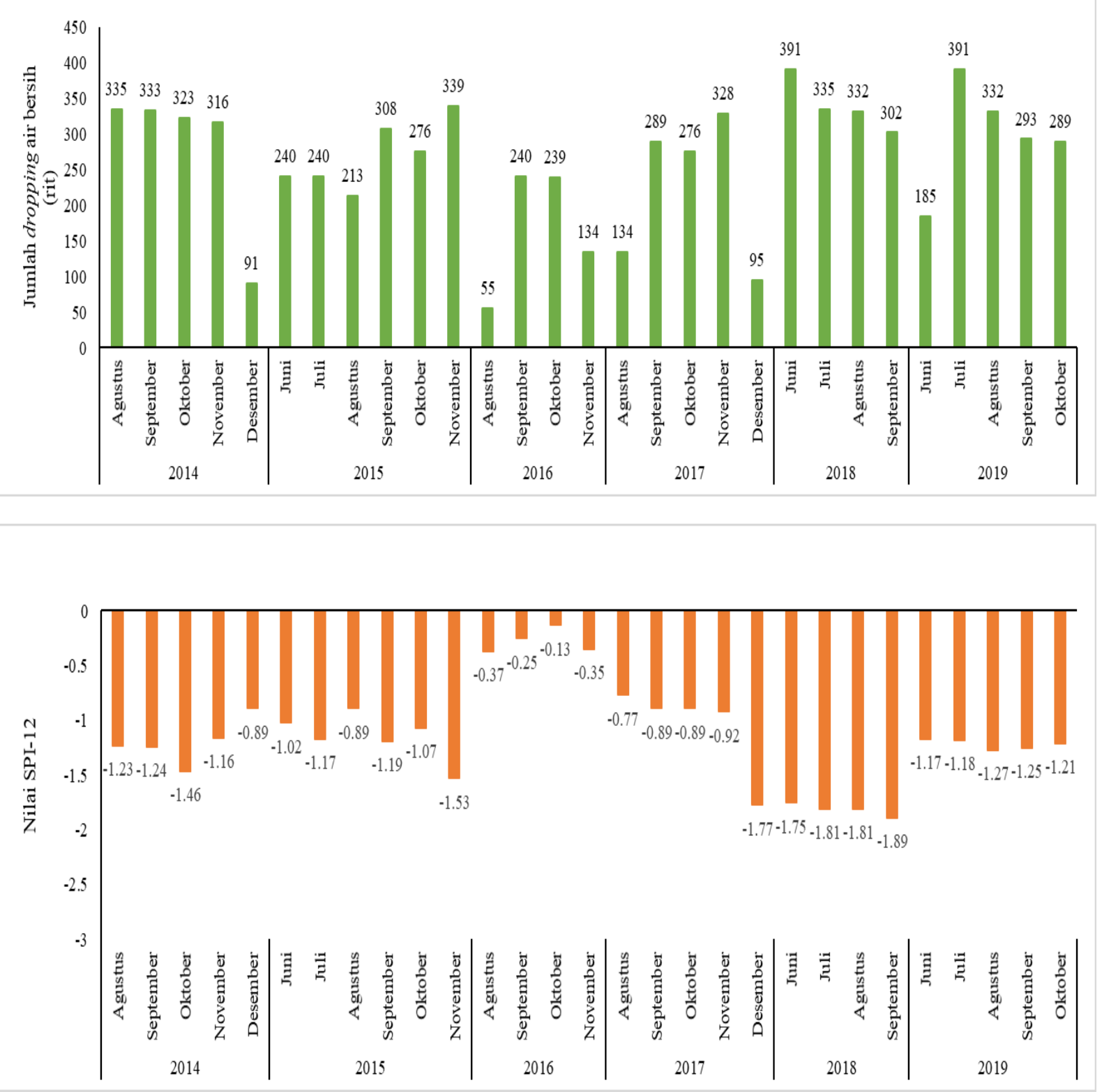

GAMBAR 5. Pola SPI-12 dengan data dropping air bersih

Berdasarkan hasil analisis, nilai indeks kekeringan tertinggi terjadi pada bulan September 2018 dengan nilai indeks -1,89 dengan kategori sangat kering. Besarnya nilai indeks kekeringan (SPI-12) pada bulan September untuk berbagai stasiun hujan selengkapnya disajikan pada Tabel 4 . 
TABEL 4. Hasil indeks kekeringan SPI-12 tahun 2018

\begin{tabular}{ccc}
\hline Stasiun Hujan & Nilai Indeks & Kategori \\
\hline Dam Umbul & $-1,33$ & Kering \\
Gedang Mas & $-1,69$ & Sangat Kering \\
Kali Penggung & $-1,69$ & Sangat Kering \\
Paleran & $-1,63$ & Sangat Kering \\
Ranuklakah & $-1,83$ & Sangat Kering \\
Ranupakis & $-1,82$ & Sangat Kering \\
Ranuyoso & $-1,89$ & Sangat Kering \\
\hline
\end{tabular}

\section{Persebaran Kekeringan}

Peta sebaran merupakan hasil analisis spasial indeks kekeringan SPI-12, peta wilayah Kabupaten Lumajang bagian utara dan peta lokasi stasiun hujan. Peta sebaran kekeringan menggunakan metode IDW dan dilakukan 6 tahun terakhir pada bulan dengan tingkat kekeringan terparah.

Dari hasil analisis spasial didapatkan kesimpulan bahwa kekeringan terparah terjadi pada bulan September 2018 dimana hampir seluruh bagian termasuk kedalam kondisi amat sangat kering. Sebaran kekeringan pada tahun 2014 sebagian besar didominasi oleh kategori kering dan sebagian lainnya normal yang ditampilkan pada Gambar 6. Sebaran kekeringan tahun 2015 didominasi kekeringan kategori sangat kering yang ditampilkan pada Gambar 7. Pada tahun 2016 dimana didominasi oleh status normal yang ditampilkan pada Gambar 8. Pada tahun 2017 sebaran kekeringan didominasi kategori sangat kering yang ditampilkan pada Gambar 9. Kekeringan pada tahun 2018 dimana didominasi kategori sangat kering dan sebagian kecil kategori kering yang ditampilkan pada Gambar 10. Sebaran kekeringan tahun 2019 seluruh wilayah mengalami status kering yang ditampilkan pada Gambar 11. 


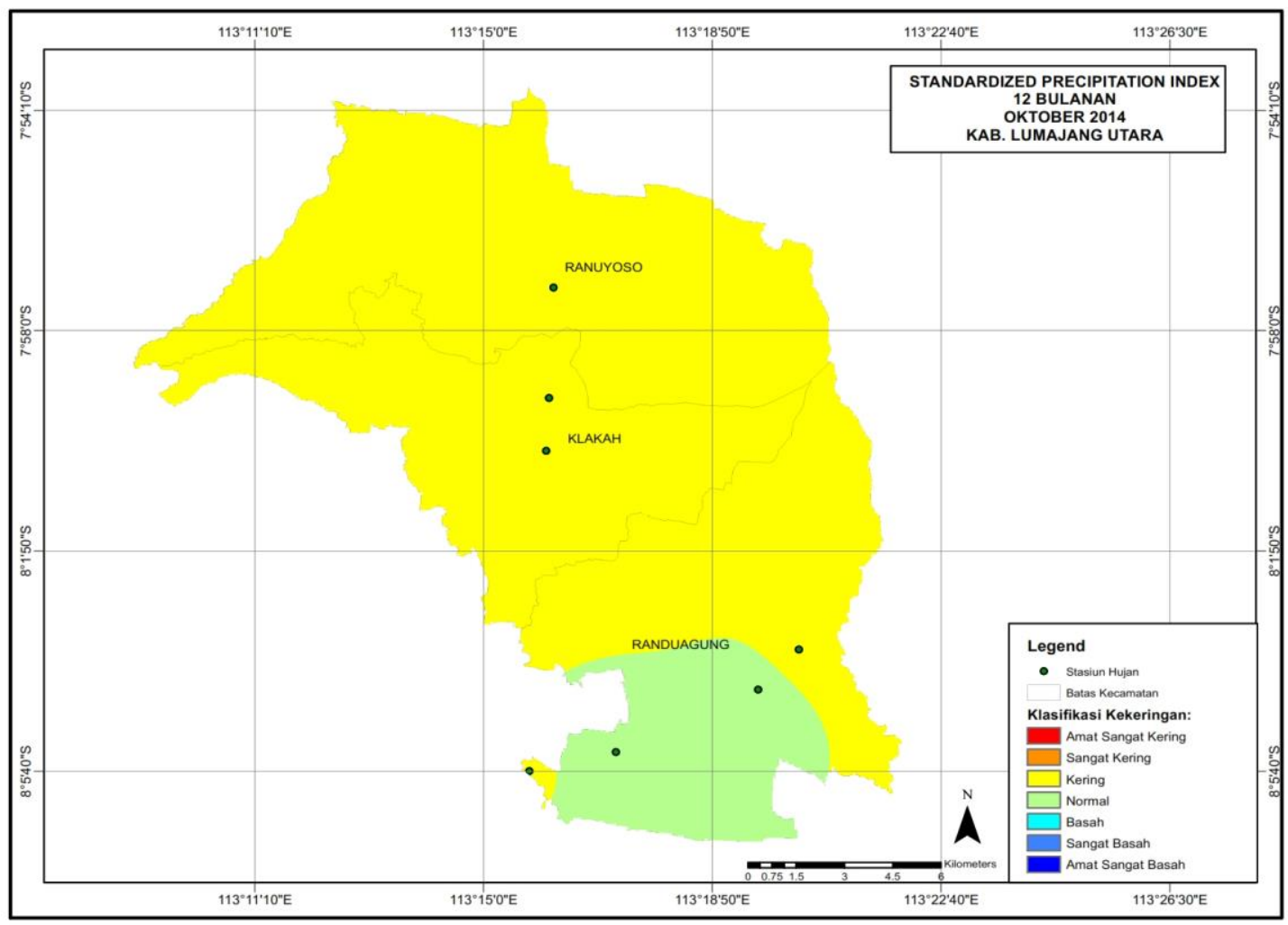

GAMBAR 6. Kekeringan tahun 2014

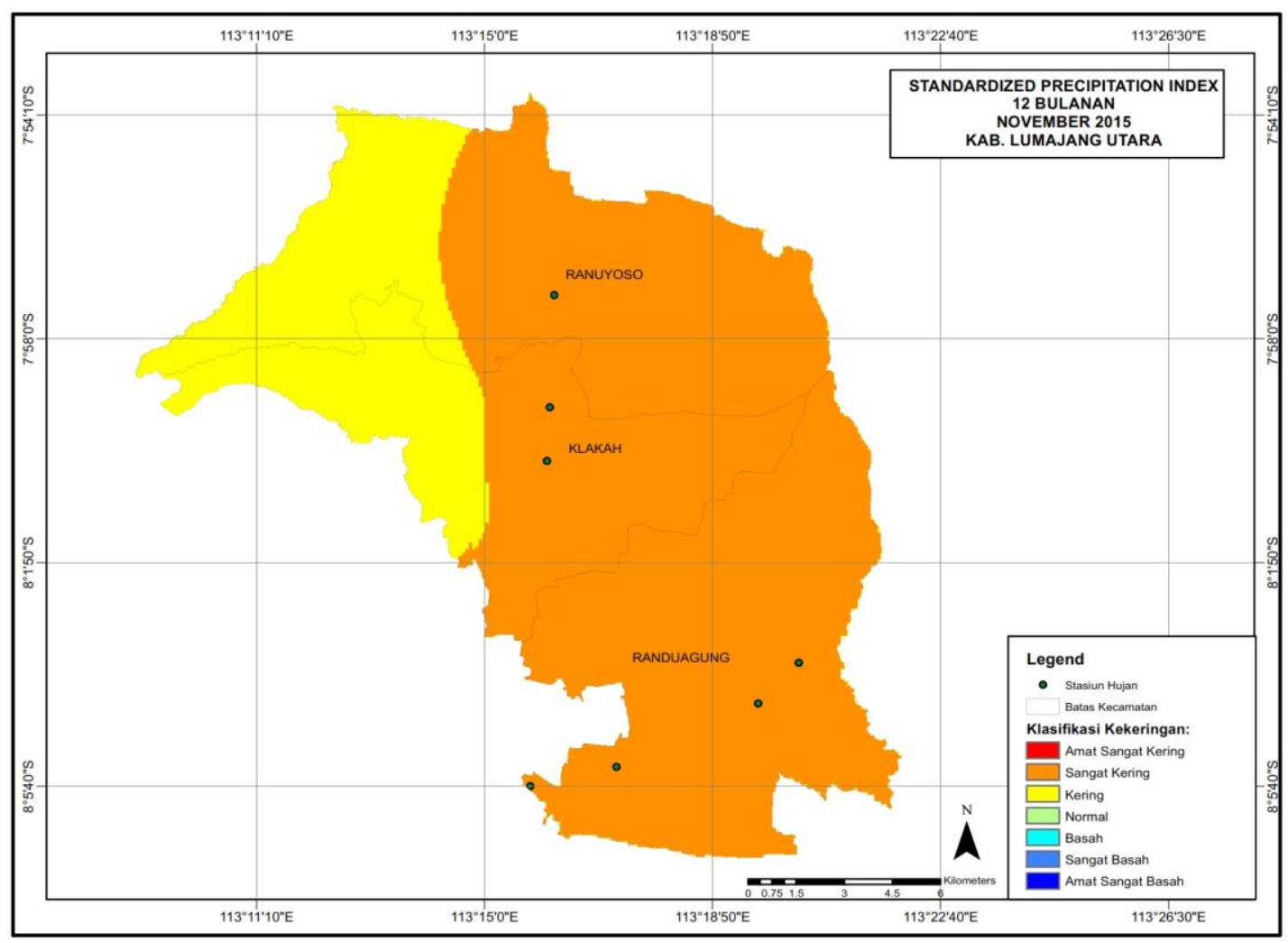

GAMBAR 7. Kekeringan tahun 2015 


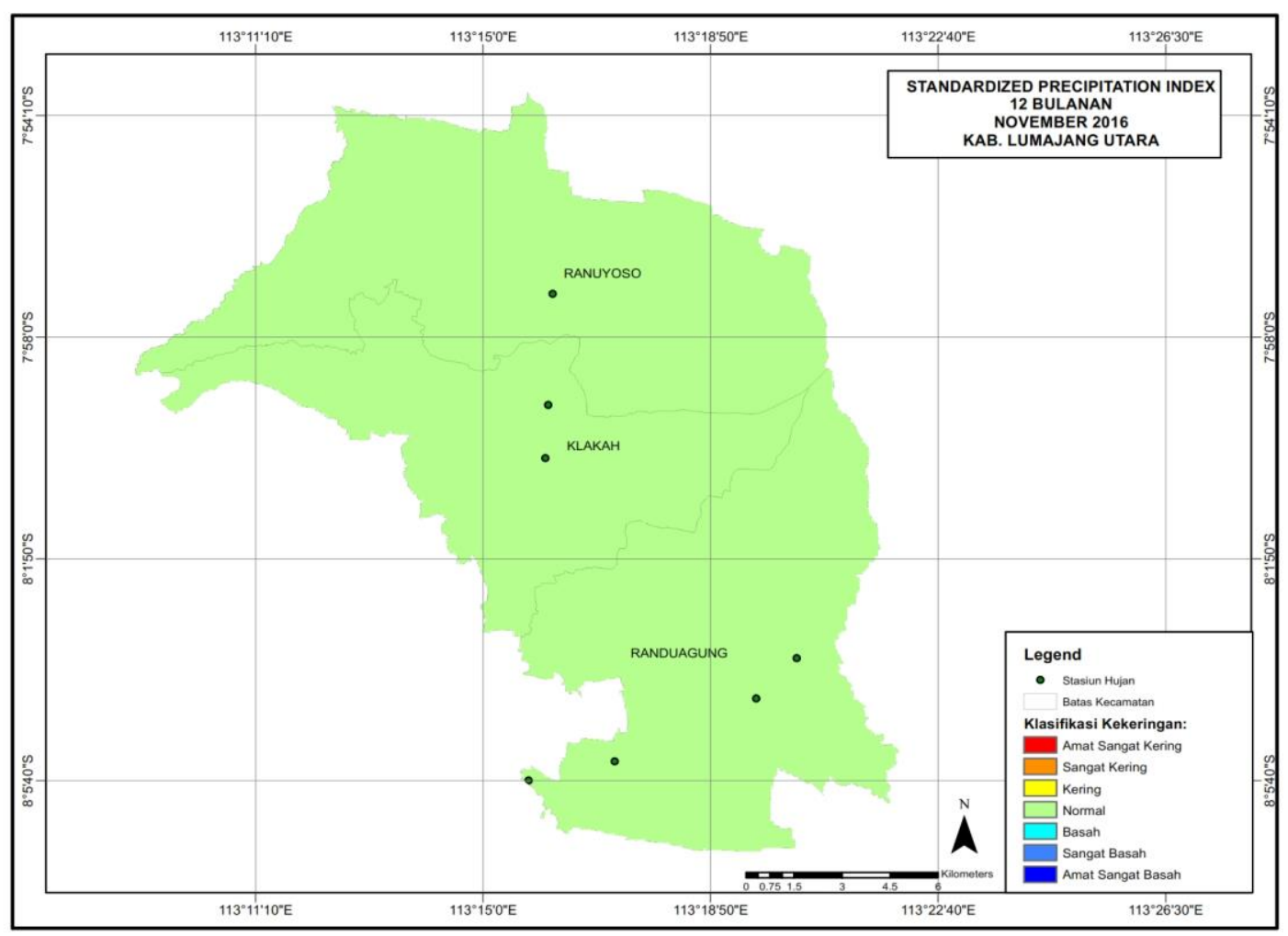

GAMBAR 8. Kekeringan tahun 2016

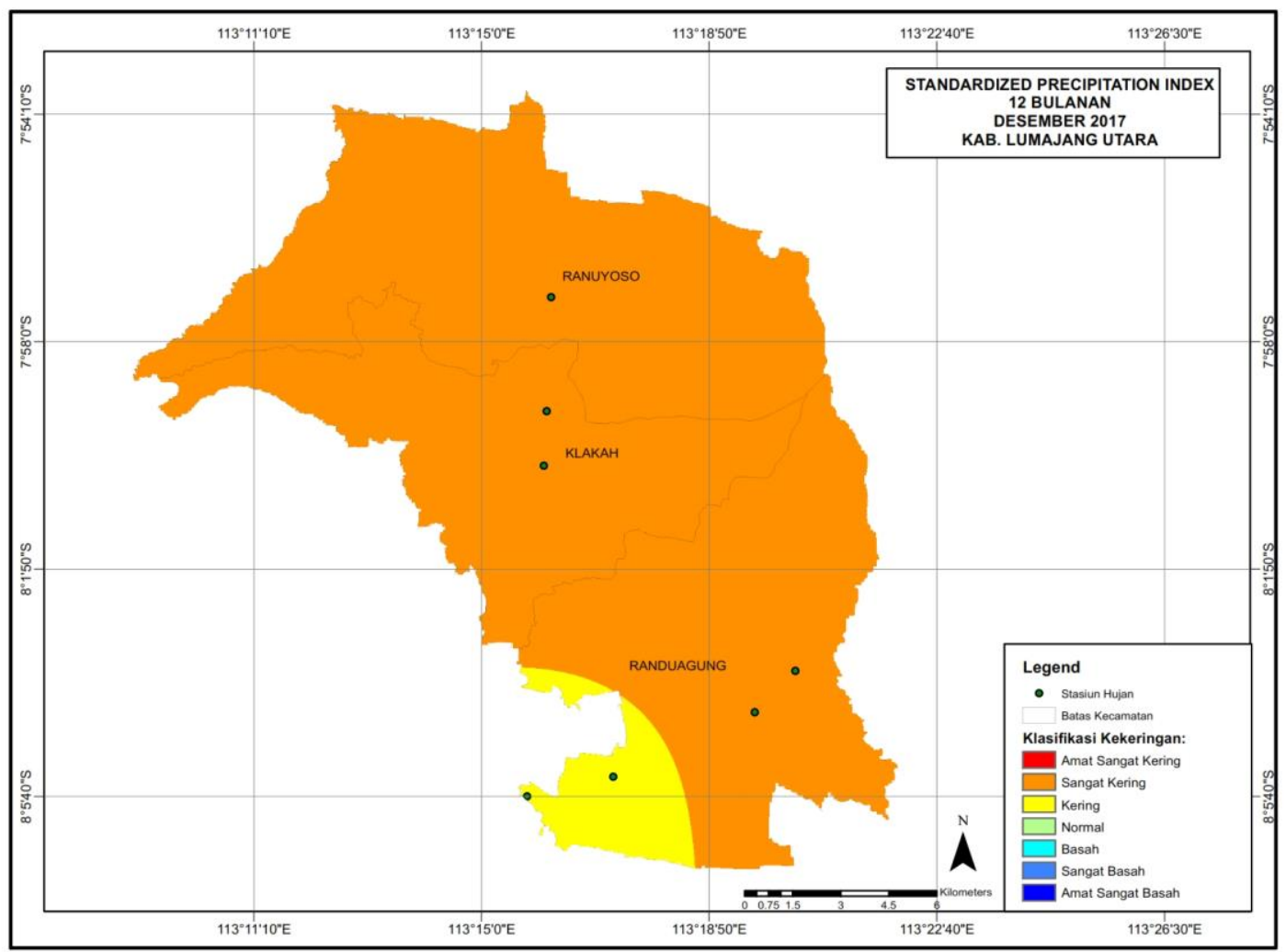

GAMBAR 9. Kekeringan tahun 2017 


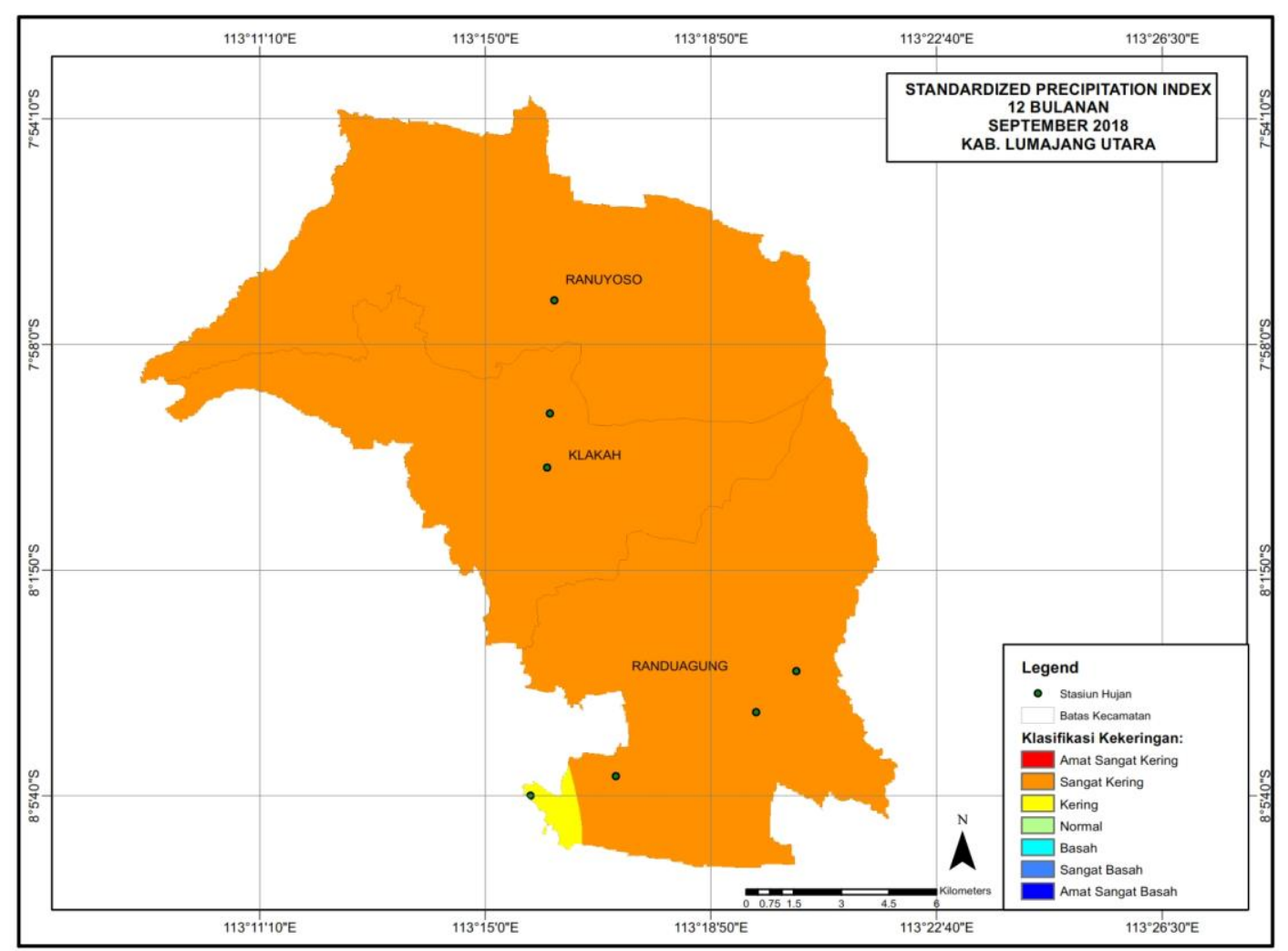

GAMBAR 10. Kekeringan tahun 2018

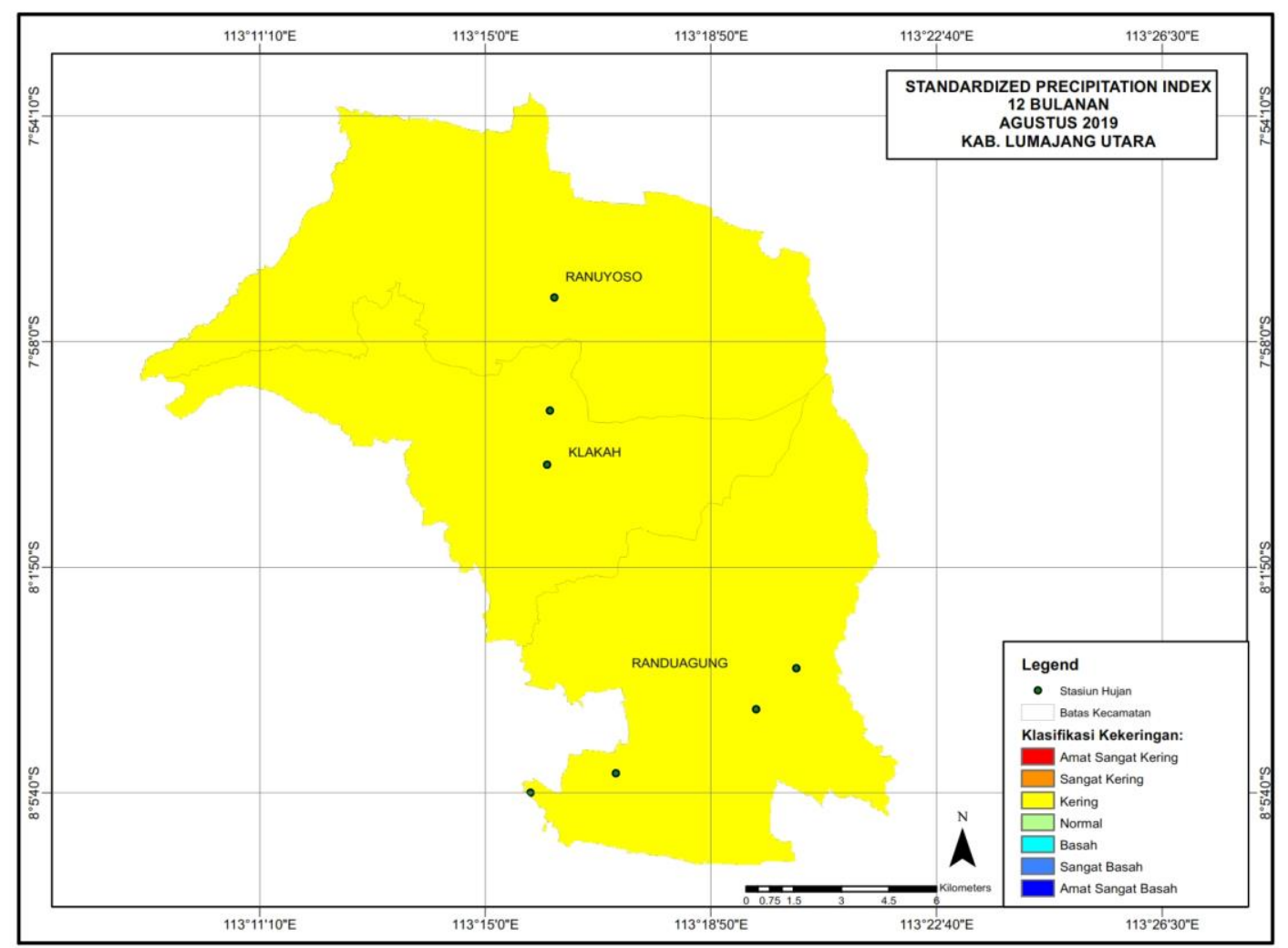

GAMBAR 11. Kekeringan tahun 2019 


\section{KESIMPULAN}

Indeks kekeringan SPI-12 tertinggi terjadi pada bulan September 2018 dengan nilai -1,89 yang termasuk kedalam status sangat kering. Sedangkan indeks kekeringan SPI-12 terendah terjadi pada bulan Maret 2001 dengan nilai 1,71 yang termasuk kedalam status sangat basah. Pada hasil sebaran kekeringan tahun 2014 didominasi status kering dan sebagian daerah lainnya berstatus normal. Sebaran kekeringan tahun 2015 didominasi status sangat kering dan sebagian daerahnya berstatus kering. Sebaran kekeringan tahun 2016 seluruh daerah berstatus normal. Sebaran kekeringan tahun 2017 didominasi status sangat kering dan sebagian daerah berstatus kering. Sebaran kekeringan tahun 2018 didominasi status sangat kering dan hanya sebagian kecil berstatus kering. Sebaran kekeringan tahun 2019 seluruh daerah berstatus kering.

\section{DAFTAR PUSTAKA}

Awchi, T. A., \& Kalyana, M. M. (2017). Meteorological drought analysis in Northern Iraq using SPI and GIS. Sustainable Water Resources Management, 3(4), 451-463. https: //doi.org/10.1007/s40899-017-0111-x.

Du, J., Fang, J., Xu, W., \& Shi, P. (2013). Analysis of dry/wet conditions using the standardized precipitation index and its potential usefulness for drought/flood monitoring in Hunan Province, China. Stochastic Environmental Research and Risk Assessment, 27(2):377-387. https://doi.org/10.1007/s00477-0120589-6.

Insani, R. A. F. (2018). Analisis kekeringan meteorologis di kabupaten Pati. (Publikasi No. 64983) [Skripsi, Universitas Muhammadiyah Surakarta] http://eprints.ums.ac.id/id/eprint/64983.

Li, Y. J., Zheng, X. D., Lu, F., \& Ma, J. (2012). Analysis of drought evolvement characteristics based on standardized precipitation index in the Huaihe River Basin. Procedia Engineering, 28, 434437. https://doi.org/10.1016/j.proeng.2012.01 .746 .
Livada, I., \& Assimakopoulos, V. D. (2007). Spatial and temporal analysis of drought in Greece using the Standardized Precipitation Index (SPI). Theoretical and Applied Climatology, 89(3-4):143153. https://doi.org/10.1007/s00704005-0227-z

Shah, R., Bharadiya, N., \& Manekar, V. (2015). Drought Index Computation Using Standardized Precipitation Index (SPI) Method For Surat District, Gujarat. Aquatic Procedia, 4, 12431249.

https://doi.org/10.1016/j.aqpro.2015.02. 162.

Stagge, J. H., Kohn, I., Tallaksen, L. M., \& Stahl, K. (2015). Modeling drought impact occurrence based on meteorological drought indices in Europe. Journal of Hydrology, 530, $37-$ 50.

https://doi.org/10.1016/j.jhydrol.2015.09 .039 .

Suwiji, N. S. Z. (2019). Kekeringan: pengertian, penyebab, dampak, dan penanggulangan. Foresteract. https://foresteract.com/kekeringan

Tatli, H. (2015). Downscaling standardized precipitation index via model output statistics. Atmosfera, 28(2), 83-98. https://doi.org/10.1016/s01876236(15)30002-3.

Wang, K-Y., Li, Q-F., Yang, Y., Zeng, M., Li, P-C., \& Zhang, J-X. (2015). Analysis of spatio-temporal evolution of droughts in Luanhe River Basin using different drought indices. Water Science and Engineering, 8(4), 282-290. https://doi.org/10.1016/j.wse.2015.11.00 4.

Widodo, N., \& Pawitan, H. (2013). Analisis dan pemetaan indeks kekeringan meteorologis menggunakan data satelit TRMM dari 36 titik stasiun BMKG di pulau Sumatera. [Skripsi, Institut Pertanian Bogor] http://repository.ipb.ac.id/handle/123456 $789 / 67416$. 


\section{Radiah Ulil Absari}

Program Studi Teknik Sipil, Fakultas Teknik, Universitas Jember, Jember.

Email: radiahuli14@gmail.com

\section{Gusfan Halik}

Program Studi Teknik Sipil, Fakultas Teknik, Universitas Jember, Jember.

Email: gusfan.teknik@unej.ac.id

\section{Wiwik Yunarni Widiarti}

Program Studi Teknik Sipil, Fakultas Teknik, Universitas Jember, Jember. 